\title{
Temporal and spatial variation in nitrogen fixation activity in the eelgrass Zostera marina rhizosphere
}

\author{
Karen J. McGlathery ${ }^{1, *}$, Nils Risgaard-Petersen ${ }^{2}$, Peter Bondo Christensen ${ }^{2}$ \\ 'Department of Environmental Sciences, Clark Hall, University of Virginia, Charlottesville, Virginia 22903, USA \\ ${ }^{2}$ National Enviromental Research Institute, Vejlsøvej 25, PO Box 314, DK-8600 Silkeborg, Denmark
}

\begin{abstract}
A perfusion technique for measuring nitrogen fixation in the eelgrass rhizosphere was developed and used to investigate the patterns and controls of nitrogen fixation in sediment cores containing live eelgrass Zostera marina plants collected from the Limfjord, Denmark. Detailed temporal and spatial patterns of acetylene reduction were consistent with the hypothesis that heterotrophic nitrogen fixation in the eelgrass rhizosphere is stimulated by organic root exudates derived from plant photosynthesis. Nitrogen fixation activity was approximately $3 \times$ higher in vegetated than unvegetated sediments, and showed strong seasonal patterns and differences in light-dark incubations that corresponded to variations in plant productivity. Rates in both the light and dark were lowest in the winter months, and increased steadily through the spring and summer to a peak activity in August that coincided with the maximum eelgrass aboveground biomass. Light-incubated cores had significantly higher rates (25 to $40 \mathrm{w}$ ) than those incubated in the dark during the growth season, and this difference was greatest during the summer months when plant productivity was highest. Nitrogen fixation activity aiso showed strong (5-fold) spatıal vanation with depth in the eelgrass root zone, with highest rates corresponding to the largest root+rhizome biomass and correlating with seasonal changes in belowground biomass distribution. Additions of glucose or $\mathrm{NH}_{4}{ }^{+}$showed that the nitrogen-fixing bacteria were limited by organic substrate and were not sensitive to $\mathrm{NH}_{4}{ }^{+}$concentrations. Molybdate additions indicated that sulfate reducers were responsible for about $25 \%$ of the nitrogen fixation activity in the eelgrass rhizosphere. Overall, daily nitrogen fixation rates integrated to a depth $14 \mathrm{~cm}$ in the sediment ( 1 to $6 \mathrm{mg} \mathrm{N} \mathrm{m}^{-2} \mathrm{~d}^{-1}$ ) were comparable to rates measured in other temperate seagrass meadows, but were lower than those determined for tropical seagrass beds.
\end{abstract}

KEY WORDS: Nitrogen fixation - Eelgrass $\cdot$ Rhizosphere $\cdot$ Sediment

\section{INTRODUCTION}

Nearshore coastal ecosystems are typically characterized by high primary production of phytoplankton and benthic macrophytes, which in temperate areas is usually limited by nitrogen availability (Nixon \& Pilson 1983, Howarth 1988). The high productivity of these temperate systems is largely supported by external inputs and by the recycling of remineralized nitrogen, but in the absence of significant external loading, new inputs from nitrogen fixation are essential to offset losses via denitrification (Capone 1988). Shallow benthic areas are believed to be the main sites of nitrogen fixation in the oceans, especially seagrass, coral reef

•E-nail:kjm4k@virginia.edu and salt marsh ecosystems, where fixation provides from $<5$ to $100 \%$ of the plant nitrogen demand (Capone 1988, Howarth et al. 1988). Heterotrophic bacteria located in the rhizosphere of both tropical and temperate seagrasses have particularly high nitrogen fixation rates, and these rates typically exceed those in nearby unvegetated sediments (Hemminga et al. 1991, O'Donohue et al. 1991a, Welsh et al. 1996a).

Submersed vascular plants strongly influence the microbially mediated $\mathrm{N}$ transformation processes within the sediments (ammonification, nitrification, denitrification, nitrate reduction, nitrogen fixation), both directly through uptake of $\mathrm{NH}_{4}{ }^{+}$and $\mathrm{NO}_{3}{ }^{-}$and indirectly by altering redox conditions in the rhizosphere (Boon et al. 1986a, b, Christensen \& Sørensen 1986, Caffrey \& Kemp 1990, 1992). Seagrasses also transport 
organic compounds synthesized during photosynthesis to the roots (Oremland \& Taylor 1977, Wetzel \& Penhale 1979, lizumi et al. 1980, Moriarty et al. 1986); some of this photosynthate is exuded to the sediment and is believed to provide an oxidizable carbon source that enhances heterotrophic bacterial activity (Moriarty \& Pollard 1982, Moriarty et al. 1986). Moriarty et al. (1986) showed that between 6 and $28 \%$ of the carbon fixed by the leaves of the tropical seagrass Halodule wrightii was translocated to the rhizomes and roots, and that about $10 \%$ of the total fixed carbon was released within $6 \mathrm{~h}$ to the surrounding sediment where it stimulated bacterial production. Bacterial growth in the seagrass rhizosphere also generally follows a diurnal cycle, which suggests a tight coupling to seagrass metabolism, with highest activity during the early part of the day decreasing in the afternoon to a low constant nighttime rate (Moriarty \& Pollard 1982).

Nitrogen fixation in seagrass sediments is often stimulated by the addition of a wide range of oxidizable organic carbon compounds (Capone \& Budin 1982, Capone 1988, Welsh et al. 1996b), and it has been suggested that the activity of heterotrophic nitrogen-fixing bacteria is associated with the release of photosynthetically derived organic carbon in both tropical and temperate seagrass beds (Capone \& Taylor 1980, Smith \& Hayasaka 1982, O'Donohue et al. 1991a, Welsh et al. 1996a). High rates of sulfate reduction and the presence of a short-lived organic pool (5 to $10 \mathrm{~h}$ ) in the rhizosphere of the tropical seagrass Halodule sp. also point to a subsurface input of organic carbon probably originating from root exudates (Blackburn et al. 1994). These sulfate-reducing bacteria may be responsible for some of the nitrogen fixation that occurs in the seagrass rhizosphere (Capone 1982, 1988, Welsh et al. 1996b).

The purpose of this study was to characterize in detail the temporal and spatial patterns of nitrogen fixation in the rhizosphere of the temperate eelgrass Zostera marina to evaluate the hypothesis that these patterns are linked to variations in seagrass productivity. We used a perfusion technique with intact vegetated cores that allowed us to measure higher resolution profiles of acetylene reduction activity in the seagrass rhizosphere than have been recorded previously, without disrupting the direct root-microbe interactions during the incubations. Large numbers of heterotrophic nitrogen-fixing bacteria have been shown to occur in the rhizosphere of $Z$. marina compared to unvegetated sediments (Shieh et al. 1989), and it is likely that these bacteria are dependent on root exudates as a source of labile organic carbon. Previous studies based on either quarterly or semi-annual measurements, and with less spatial detail in slurry or perfusion incubations, have shown that nitrogen fixation activity in the seagrass rhizosphere was highest during the plant's most active growth period for the subtropical seagrass Zostera capricorni (O'Donohue et al. 1991 a) and the temperate species Zostera noltii (Welsh et al. 1996a) and Z. marina (Smith \& Hayasaka 1982). We measured depth profiles of acetylene reduction activity with a $2 \mathrm{~cm}$ spatial resolution at nearly monthly intervals during a full cnnual cycle. Our study is also the first to relate directly variation in depth profiles of acetylene reduction activity during light and dark incubations to the biomass and distribution of eelgrass roots and rhizomes. To determine both the extent to which nitrogen fixation was enhanced by organic substrate or inhibited by $\mathrm{NH}_{4}{ }^{+}$(Capone 1988), intact vegetated cores or sediment slurries were amended with additions of organic carbon or $\mathrm{NH}_{4}{ }^{+}$in separate experiments. Finally, eelgrass sediment cores were perfused with molybdate, a specific inhibitor of sulfate reduction (Taylor \& Oremland 1979, Oremland \& Capone 1988), to determine the contribution of sulfate-reducing bacteria to nitrogen fixation activity.

\section{METHODS}

Site description. This study was conducted from January through December 1995 in the Limfjord $\left(57^{\circ} \mathrm{N}\right.$, $9^{\circ} \mathrm{E}$ ), a shallow bay in northerm Jutland, Denmark. The site chosen for this work was the same as that used in an integrated study of the effect of benthic primary producers on the nitrogen balance in Danish shallow marine waters, and was colonized by patchy, dense seagrass beds ( 960 to 1500 shoots $\mathrm{m}^{-2}$ ). A detailed characterization of the aboveground (leaves) and belowground (roots+rhizomes) biomass of Zostera marina at the study site was made during 2 intensive field campaigns, one in April at the onset of rapid growth and the second in August at the time of maximum eelgrass biomass (N. Risgaard-Petersen, S. Rysgaard, P. B. Christensen, J. Borum, K. J. McGlathery \& L. P. Nielsen unpubl.). Belowground biomass was most dense in the upper $6 \mathrm{~cm}$ of the sediments, but fine roots reached to a depth of at least $14 \mathrm{~cm}$. The sediments were comprised of fine sands with an organic content of $<1 \%$.

Perfusion technique. Rates of acetylene reduction were measured on intact sediment cores containing live eelgrass plants $(9.3 \mathrm{~cm}$ diameter plexiglass core; sediment depth of $14 \mathrm{~cm}$, water column depth of $20 \mathrm{~cm}$ ). A perforated PVC bottom was attached to each core and the sediment pore water was slowly drained by vacuum into a reservoir, temporarily replacing the pore water with water overlying the sediment that was obtained at the time of coring (Fig. 1). A subsample of the anoxic pore water was placed into a laminated plastic bag (NEN/PE 80/100, Danisco Flexible Otto Nielsen a/s, Denmark) in which the headspace was 


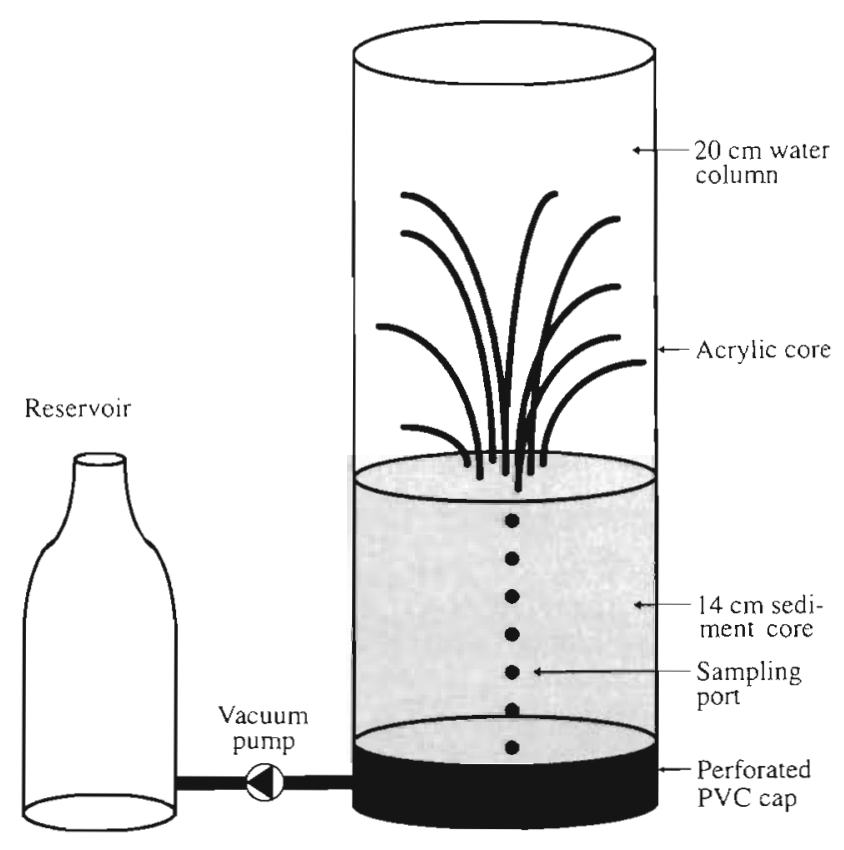

Fig. 1. Diagram of perfusion apparatus used for aceytlene reduction studies. Pore water was drained by vacuum into a reservoir through a perforated PVC cap attached to each core. The acetylene-amended pore water was drawn back into the intact sediment core by vacuum. Depth profiles of acetylene reduction activity were obtained by sampling with needle and syringe from silicone-filled holes located at $2 \mathrm{~cm}$ intervals in the clear acrylic core wall

filled with acetylene gas, and the bag was shaken to equilibrate the liquid and gas phases. The water sample was then added back to the reservoir to achieve a final acetylene concentration of $20 \%(\mathrm{v} / \mathrm{v})$, and the amended pore water was drawn back into the intact sediment core by vacuum. At the end of a 6 to $8 \mathrm{~h}$ incubation, depth profiles of acetylene reduction rates in the rhizosphere were made by taking duplicate $1 \mathrm{ml}$ sediment pore water samples with a syringe and needle through silicone-filled holes located at $2 \mathrm{~cm}$ intervals $(1,3,5,7,9,11,13 \mathrm{~cm}$ depth) in the core wall. Twenty-four hour time course experiments confirmed that 6 to $8 \mathrm{~h}$ was the optimal incubation time in which a linear response could be measured accurately without the artifacts of a lag in response that can sometimes occur with too short an incubation time $(0.5$ to $2 \mathrm{~h})$, or of substrate depletion from too long an incubation time (>12 h) (Capone 1982, Seitzinger \& Garber 1987).

The perfusion process took $<5$ min per core and there was no visual indication of compaction of the core or channeling of the perfused pore water in the sandy sediments. Detailed spatial sampling of acetylene concentrations in the sediment core through multiple series of silicone holes in the core wall showed that the acetylene was uniformly distributed throughout the sediment core. This perfusion technique is par- ticularly suitable for measuring nitrogen fixation rates in sandy sediments, but may be less effective for sediments with a high clay content. Bromide additions to the water column of the experimental cores showed that the sampling did not result in appreciable dilution of sediment pore water by drawing water down from the overlying water column $(<5 \%$ dilution for samples taken from the upper $3 \mathrm{~cm}$ of sediment, and $<1 \%$ in the deeper layers). Oxygen and nutrient gradients were disturbed by the perfusion process, but, unlike the continuous perfusion of sediment cores described by Capone \& Carpenter (1982) where pore water is constantly flushed through the sediment core, the short perfusion time and subsequent 6 to $8 \mathrm{~h}$ incubation probably allowed microgradients to become reestablished around the roots because nutrient turnover time in the pore water is high (Capone 1982, Boon et al. 1986a, O'Donohue et al. 1991b). Pore water samples taken during the incubation period also smelled strongly of $\mathrm{H}_{2} \mathrm{~S}$, indicating anoxic conditions in the rhizosphere. The advantages of this perfusion technique are that it maintains the direct root-microbe interactions during the incubation period that are disturbed using the slurry method, and also avoids the potential release of labile organic carbon compounds from damaged roots that may be a source of error in slurry incubations (O'Donohue et al. 1991b. Hines et al. 1994, Welsh et al 1996a). The perfusion method also has a distinct advantage over the lacunal diffusion technique, because the latter relies on gas exchange through the plant lacunal system and may only saturate bacteria adjacent to the roots due to slow diffusion rates in the sediments (O'Donohue et al. 1991b, Welsh et al. 1996a). This may result in uneven and unsaturating concentrations of acetylene below the root zone (O'Donohue et al. 1991b, Moriarty \& O'Donohue 1993) and an underestimation of nitrogen fixation rates.

Pore water samples were stored in $3 \mathrm{ml}$ evacuated tubes (Venoject) containing $25 \mu \mathrm{ZnCl}_{2}(50 \% \mathrm{w} / \mathrm{w})$ to stop bacterial activity, and were analyzed for acetylene and ethylene concentrations within a week of sampling. Separate time course studies showed that samples could be preserved for this time period without measurable loss of ethylene from the tubes. Ethylene and acetylene concentrations were measured by flame ionization gas chromatography on a sample taken from the headspace after several minutes of shaking to equilibrate the liquid and gas phases. Sediment porosity was determined from weight differences before and after drying a known volume of sediment at $105^{\circ} \mathrm{C}$ for $24 \mathrm{~h}$. Acetylene reduction rates at each depth were calculated using the appropriate Bunsen coefficient as

$$
\Delta C \varphi / \Delta t
$$

where $\Delta C$ is the measured change in pore water ethyl- 
ene accounting for the ethylene present in the pore water at the start of the incubation, $\varphi$ is the sediment porosity, and $\Delta t$ is the incubation time. To determine the potential effect of the vertical diffusion of ethylene on our results, we recalculated the acetylene reduction rates using a modified version of the discrete approximation of Fick's second law given by Rysgaard \& Berg (1996). These calculations gave the same ethylene production rates within $1 \%$, indicating that the diffusive transport of ethylene during the incubation period was insignificant. Acetylene reduction rates were related to nitrogen fixation rates using the stoichiometric relationship of $1 \mathrm{~mol}$ dinitrogen fixed for every 3 mol acetylene reduced. Though this ratio is known to vary in marine sediments (Seitzinger \& Garber 1987), we based our calculations on the calibration of acetylene reduction with ${ }^{15} \mathrm{~N}_{2}$ fixation made by O'Donohue et al. (1991a) in Zostera capricorni sediments; which showed little departure from the theoretical 3:1 ratio. Results are reported as calculated nitrogen fixation rates on an area or volume basis.

Temporal patterns of nitrogen fixation activity. On each of the sampling dates during 1995, 8 replicate cores containing live eelgrass plants were collected and held overnight in a water bath in a temperature-controlled incubation room, and were processed the following day to determine nitrogen fixation activity. Acetylene was added to the sediment pore water using the perfusion technique, and then half the cores were incubated in the light and half in the dark (representing day and night, respectively) at in situ temperatures. The illuminated cores were submerged in an outdoor bath of seawater taken from the site. The water column above the cores was a similar depth to that in the field at low tide so that the incubation light intensities were as similar as possible to field light intensities. A comparison of depth profiles of acetylene reduction activity in vegetated and bare sediments was made in October

Carbon, ammonium and molybdate effects on nitrogen fixation. Twelve sediment cores containing intact eelgrass plants were incubated in laboratory experiments during June 1995 to determine the extent of carbon limitation of the heterotrophic nitrogen-fixing bacteria. Pore water was drained from the cores, and a source of labile dissolved organic carbon $(1 \mathrm{mM}$ glucose) was added with acetylene $(20 \% \mathrm{v} / \mathrm{v})$ to the reservoir of half the cores. The other 6 cores received acetylene additions only and served as controls. Half of the cores ( 3 glucose amended, 3 controls) were then incubated in the dark and half at the in situ light level. After a $6 \mathrm{~h}$ incubation, detailed pore water samples were taken as described above and analyzed for acety. lene reduction activity.

The interaction of pore water $\mathrm{NH}_{4}{ }^{+}$concentrations and acetylene reduction activity in the seagrass rhizo- sphere was determined both at in situ $\mathrm{NH}_{4}{ }^{+}$levels and in $\mathrm{NH}_{4}{ }^{+}$addition experiments. First, depth profiles of acetylene reduction activity were made in June 1995 in triplicate perfused cores containing intact eelgrass plants as described above, and acetylene reduction rates were correlated with pore water $\mathrm{NH}_{4}{ }^{+}$concentrations from the same depth interval. For the $\mathrm{NH}_{4}{ }^{+}$analysis, $1 \mathrm{ml}$ of pore water from each $2 \mathrm{~cm}$ depth interval was removed through the silicone-filled holes in the core wall using a needle and syringe, and concentrations were determined immediately using the salicylate-hypochlorite method of Bower \& Holm-Hansen (1980). Second, we tested the effect of $\mathrm{NH}_{4}{ }^{+}$additions on acetylene reduction activity in slurry incubations of sediment collected from the depth interval of maximum activity in the eelgrass rhizosphere. We chose slurry incubations for this experiment so that we could isolate the effects of varying levels of $\mathrm{NH}_{4}{ }^{+}$on acetylene reduction activity in the sediment from responses linked to variations in plant activity. The 2 to $6 \mathrm{~cm}$ depth intervals from 6 vegetated cores were pooled, and $6 \mathrm{~cm}^{3}$ of sediment was added to 4 replicate $11 \mathrm{ml}$ gas-tight vials with Butyl-rubber stoppers (Exetainer, Labco, High Whycombe, UK) for each of 5 treatments: no $\mathrm{NH}_{4}{ }^{+}$addition (control), and 200,400, 600 and $800 \mathrm{\mu M} \mathrm{NH}_{4}^{+}$additions. The vials were immediately filled with $\mathrm{N}_{2}$-bubbled nutrient-free seawater amended with acetylene $(20 \% \mathrm{v} / \mathrm{v})$ and the appropriate $\mathrm{NH}_{4}{ }^{+}$ concentration, and were incubated for $6 \mathrm{~h}$ on a shaker table. At the end of the incubation, the vials were shaken vigorously to form a suspension and a $1 \mathrm{ml} \mathrm{sub-}$ sample was removed with a needle and syringe and immediately placed in a $3 \mathrm{ml}$ Venoject containing $25 \mu \mathrm{I}$ $50 \%$ (w/w) $\mathrm{ZnCl}_{2}$ to stop bacterial activity. Ethylene concentrations were measured by gas chromatography as described above, and net reduction rates of acetylene were calculated and expressed on a $g$ dry weight (g.DW) basis

Molybdate $(20 \mathrm{mM})$ was added as $\mathrm{Na}_{2} \mathrm{MoO}_{4}$ using the perfusion technique to cores containing live eelgrass plants to determine the extent to which sulfatereducing bacteria were responsible for the patterns of nitrogen fixation in these sediments. The cores were incubated in triplicate in the light for $6 \mathrm{~h}$ and acetylene reduction rates measured as described above.

Nitrogen fixation in excised roots and rhizomes. To determine the relative contribution by heterotrophic bacteria either attached to or embedded within the eelgrass roots and rhizomes to the total nitrogen fixation activity in the rhizosphere, separate measurements of acetylene reduction were made on roots and rhizomes picked out of vegetated sediment cores. Roots and rhizomes were incubated separately $(n=4)$ in $11 \mathrm{ml}$ glass vials (Exetainer, Labco) to which $20 \%$ (v/v) acetylenesaturated, nutrient-free seawater was added. Incuba- 
tions lasted for $6 \mathrm{~h}$ and samples were shaken continuously. One set of roots and rhizomes was separated from the sediments under anoxic conditions and incubated in anoxic seawater. The second set was exposed to oxygen during both processing and incubation. At the end of the incubation, a $1 \mathrm{ml}$ subsample was drawn from the incubation vial and placed into a $3 \mathrm{ml}$ Venoject containing $25 \mu \mathrm{l}$ of $50 \%(\mathrm{w} / \mathrm{w}) \mathrm{ZnCl}_{2}$, and ethylene concentrations were measured on gas samples drawn from the headspace after shaking to equilibrate the water and gas phases. A set of root and rhizome incubations also were run under both oxic and anoxic conditions, to which nutrient-free seawater was added without acetylene. This was done to check if ethylene was produced by the excised roots and rhizomes as a damage response, independent of acetylene reduction.

\section{RESULTS}

\section{Depth-integrated nitrogen fixation rates}

The set of whole-core incubations with no acetylene added to the perfused water showed that ethylene was not produced from root damage during the perfusion and incubation procedures independent of acetylene reduction, and that the perfused pore water could be used as an appropriate blank for the entire denth profile. In addition, there was no measurable nitrogen fixation activity in 6 to $8 \mathrm{~h}$ incubations of excised roots and rhizomes, regardless of the treatment (oxic vs anoxic). There also was no ethylene produced from root damage in the control incubations of roots and rhizomes that were incubated without the addition of acetylene.

Heterotrophic nitrogen fixation was stimulated by the presence of eelgrass, and showed strong temporal variations in activity that corresponded to the general seasonal pattern of plant productivity (Pedersen \& Borum 1993). Rates of nitrogen fixation integrated to a depth of $14 \mathrm{~cm}$ in the eelgrass rhizosphere ranged from about 4 to $20 \mu \mathrm{mol} \mathrm{N} \mathrm{m}^{-2} \mathrm{~h}^{-1}$ (Fig. 2). There was a strong seasonal variation in nitrogen fixation activity (repeated-measures ANOVA: $F_{7,21}=25.9, p<0.0001$ ), where rates in both the light and dark were lowest in the winter months, and increased steadily through the spring and summer to a peak activity in August that coincided with the maximum eelgrass biomass (Risgaard-Petersen et al. unpubl.). Rates in the light-incubated cores declined during the fall and winter months as temperatures and eelgrass productivity also declined. There was a slight increase in dark nitrogen fixation activity during the fall.

Depth-integrated nitrogen fixation activity also showed significant variation between light and dark incubations throughout the year (Fig. 2; repeated-mea-

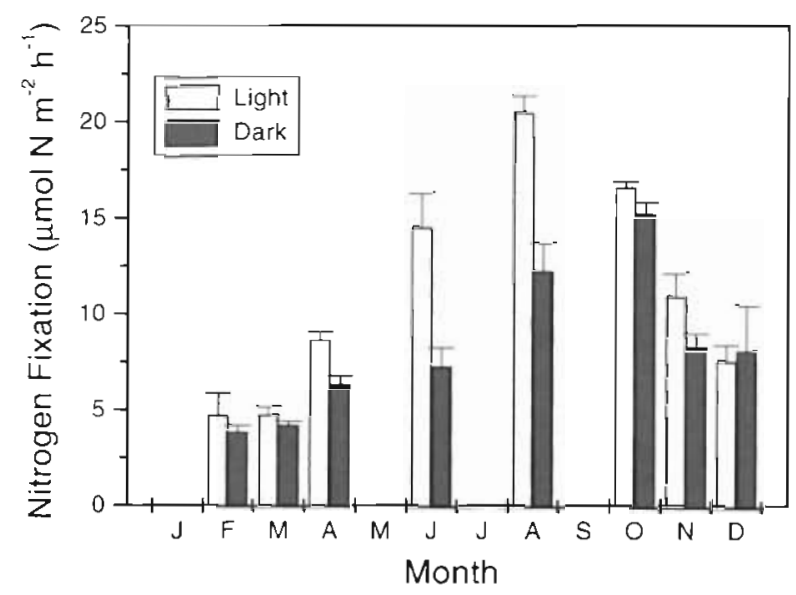

Fig. 2. Seasonal variation in depth-integrated nitrogen fixation activity (acetylene reduction) in sediments colonized by Zostera marina. Sediment cores were perfused with acetylene-saturated pore water and incubated at in situ temperature and light levels for $6 \mathrm{~h}$. Values represent means $(\mathrm{n}=3)$ $+1 \mathrm{SE}$

sures ANOVA: $F_{\overline{7}, 21}=3.69, \mathrm{p}=0.009$ ), with cores incubated in the light having consistently higher rates than those incubated in the dark, except during the winter when bacterial and plant productivity were both negligible (Fig. 2). This difference was greatest when plant productivity was highest during the summer months, when light-incubated rates were 40 to $50 \%$ higher than dark-incubated rates (Fig, 2).

\section{Depth profiles of nitrogen fixation}

Nitrogen fixation rates were typically $3 \times$ higher in vegetated than in unvegetated sediments, and activity in the eelgrass rhizosphere showed a marked variation with depth that was absent in the bare sediments (Fig. 3; repeated-measures ANOVA: $F_{6,18}=2.92, p=$ $0.036)$. This depth variation in nitrogen fixation was apparent throughout the year in the eelgrass rhizosphere in both the light (repeated-measures ANOVA: $F_{42,114}=5.11, \mathrm{p}<0.0001$ ) and dark (repeated-measures ANOVA: $F_{42,126}=4.60, p<0.0001$ ), but was most prominent during the summer months (Fig. 4). Depthspecific rates of nitrogen fixation showed that activity was low throughout the rhizosphere in both the light (Fig. 4A) and dark (Fig. 4B) incubations during the winter and early spring, and then reached a subsurface maximum in activity in the spring and early summer that was $4 \times$ higher than the low rates measured in the top and bottom few $\mathrm{cm}$ of the sediment core. Nitrogen fixation rates were highest throughout the rhizosphere in summer and showed a strong (5-fold) spatial variation, with maximum activity in the surface layers of the sediment core (Fig. 4). During the fall, nitrogen fixation 


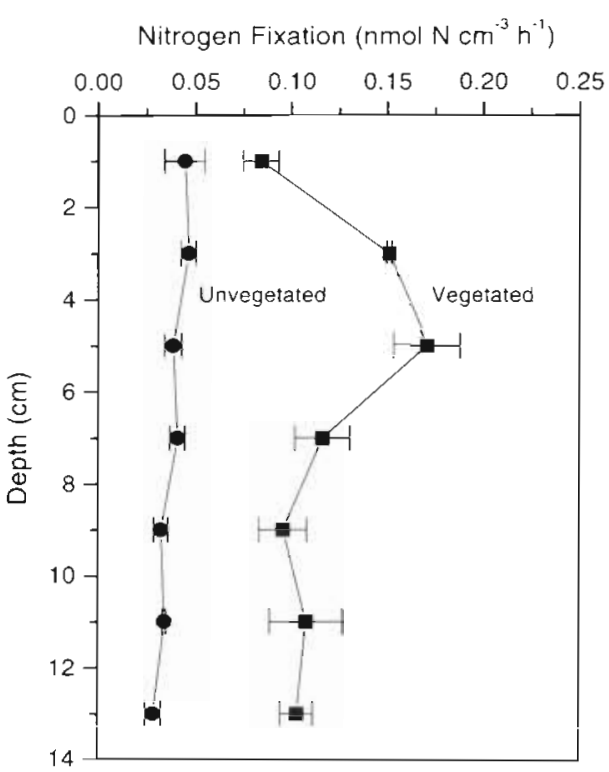

Fig. 3. Comparison of depth profiles of nitrogen fixation activity (acetylene reduction) in sediments colonized by Zostera marina and in nearby uncolonized sediments. Values represent means $(n=3) \pm 1$ SE

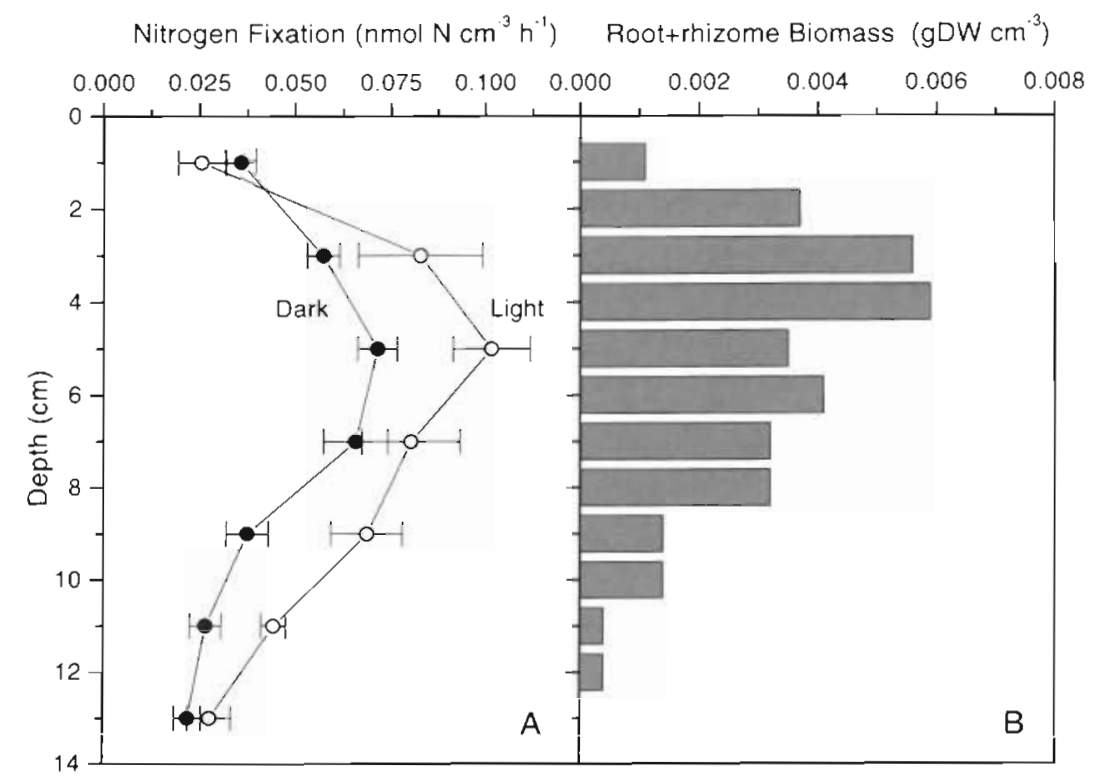

Fig. 5. Comparison of depth profiles of (A) nitrogen fixation (acetylene reduction) activity in Zostera marina vegetated cores incubated under light and dark conditions (means $\pm S E, n=3$ ) and $(B)$ belowaround root+rhizome biomass of Z. marina at the spring onset of rapid growth in April. Biomass was estimated from pooled samples $(n=3)$

$6 \mathrm{~cm}$ depth, where the seagrass belowground biomass was also maximal (Fig. 5). In August, when eelgrass biomass was highest, the zone of maximum nitrogen fixation moved upward to the top 0 to $2 \mathrm{~cm}$ of sediment (Fig. 6A) and was correlated with a similar shift in root+rhizome biomass (Fig. $6 B_{;} r=0.723, p=0.004, n=$ 14). Depth-specific nitrogen fixation rates were about $2 \times$ higher in light-incubated cores than in cores incubated in the dark (Fig. 6A). Belowground biomass of $Z$. marina was roughly $3 \times$ higher at the depth interval where it reached its maximum in August than in April and corresponded to an increase in nitrogen fixation rates of the same magnitude (Fig. 5).

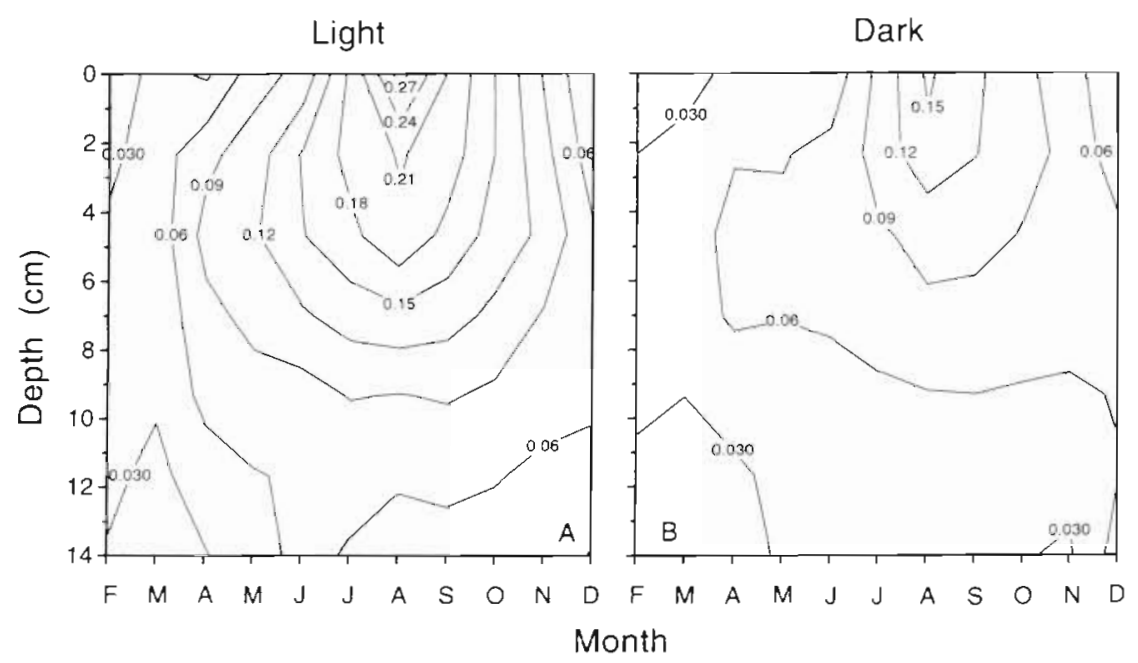

Fig. 4. Depth distribution and seasonal variation of nitrogen fixation activity (acetylene reduction) in perfused sediment cores vegetated by Zostera marina during $6 \mathrm{~h}$ (A) light and (B) dark incubations. Duplicate pore water samples were taken at $2 \mathrm{~cm}$ depth intervals on triplicate cores for each treatment for the 8 sampling dates. Units are nmol $\mathrm{N} \mathrm{cm}^{-3} \mathrm{~h}^{-1}$ 


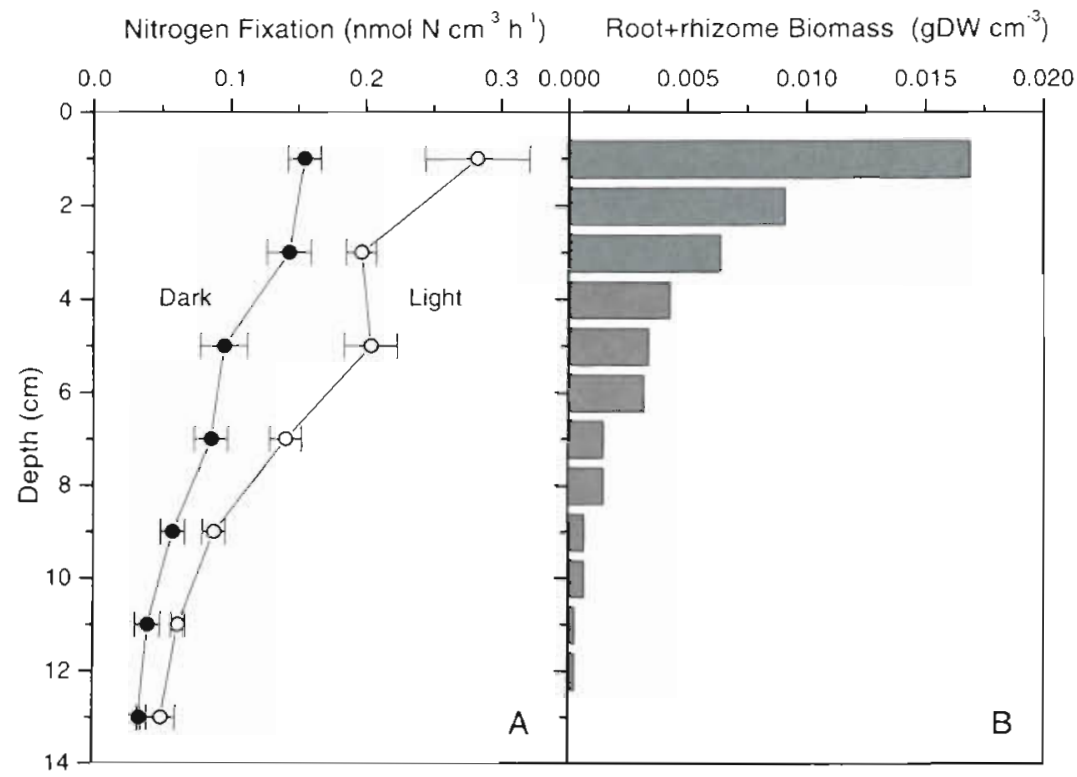

Fig. 6. Comparison of depth profiles of (A) nitrogen fixation (acetylene reduction) activity in Zostera marina vegetated cores incubated under light and dark conditions (means $\pm S E, n=3$ ) and ( $B$ ) belowground root+rhizome biomass of 2. marina at the summer peak in seagrass biomass in August. Biomass was estimated from pooled samples $(n=6)$

\section{Factors controlling nitrogen fixation in the eelgrass rhizosphere}

Depth-integrated nitrogen fixation rates were nearly 2 -fold higher in carbon-amended cores that were incubated in both the light and dark compared to controls to which only acetylene was added [Fig. 7 ; $t$-test: $\mathrm{p}<$ 0.06 (light), $p<0.003$ (dark)]. The depth profile also shows that both dark and light rates of nitrogen fixation were stimulated throughout the rhizosphere, and that the largest increase occurred in the upper $5 \mathrm{~cm}$, where the root+rhizome biomass was highest (Fig. 8).

Pore water $\mathrm{NH}_{4}{ }^{+}$was found to have no negative effect on nitrogen fixation acitivity, even at in situ concentrations up to $650 \mu \mathrm{M}$ (Fig. 9). This was shown both in the absence of $\mathrm{NH}_{4}{ }^{\top}$ inhibition in the $\mathrm{NH}_{4}{ }^{+}$addition

Table 1. Rates of anaerobic nitrogen fixation (acetylene reduction of sediment from Zostera marina beds incubated for $6 \mathrm{~h}$ in slurries with different levels of $\mathrm{NH}_{4}{ }^{+}$additions. Values are means ( $\pm 1 \mathrm{SE}$ )

\begin{tabular}{|cc|}
\hline $\begin{array}{c}\mathrm{NH}_{4}{ }^{+} \text {addition } \\
(\mu \mathrm{M})\end{array}$ & $\begin{array}{c}\text { Acetylene reduction } \\
\left(\mathrm{nmol} \mathrm{C}_{2} \mathrm{H}_{4} \mathrm{gDW}^{-1} \mathrm{~h}^{-1}\right)\end{array}$ \\
\hline $\begin{array}{cc}\text { Control } \\
+200\end{array}$ & $0.058(0.003)$ \\
+400 & $0.061(0.003)$ \\
+600 & $0.062(0.003)$ \\
+800 & $0.055(0.003)$ \\
\hline
\end{tabular}

experiments (Table 1; ANOVA: $F_{4,14}=$ $0.61, p=0.662$ ), and in the lack of a negative correlation between in situ $\mathrm{NH}_{4}{ }^{+}$concentrations and acetylene reduction in perfused cores (Fig 9). There was actually a positive correlation between in situ $\mathrm{NH}_{4}{ }^{*}$ levels and acetylene reduction $(\mathrm{r}=0.349, \mathrm{p}=0.04$, $\mathrm{n}=36$ ).

Sulfate reducers appear to be responsible for at least part of the nitrogen fixation activity. Additions of molybdate with acetylene to the pore water using the perfusion technique decreased nitrogen fixation activity in the light by $25 \%$ (Fig. 7; t-test: $\mathrm{p}=$ 0.244 ). This response is also shown in the depth profile of nitrogen fixation in the eelgrass root zone (Fig. 10), where molybdate additions reduced nitrogen fixation activity throughout the depth profile in the light-incubated cores.

\section{DISCUSSION}

The temporal patterns of nitrogen fixation rates integrated to a depth of $14 \mathrm{~cm}$ in the Zostera marina vegetated sediment indicated a clear coupling between plant productivity and heterotrophic bacterial activity in the seagrass rhizosphere. This was evident both in the absolute magnitude of nitrogen fixation, which showed a variation that was consistent with the annual trends in plant biomass and productivity typical of temperate populations (Pedersen \& Borum 1993), and in

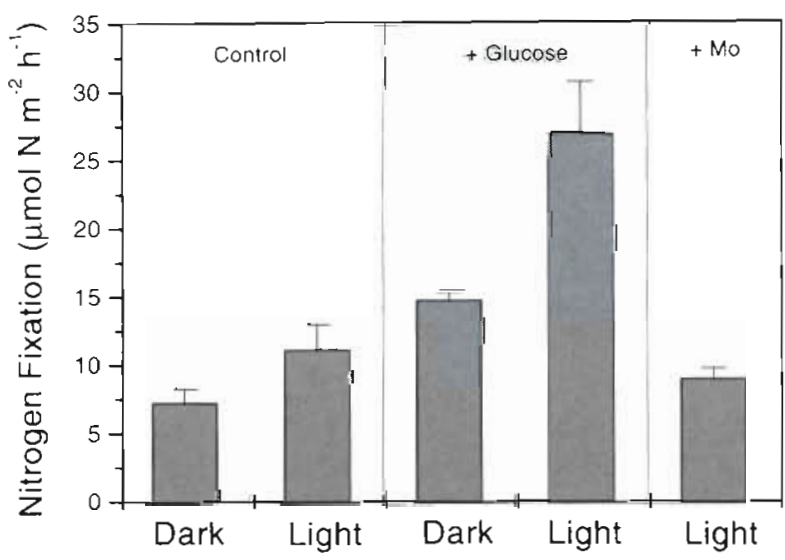

Fig 7. Depth-integrated rates (means $+\mathrm{SE}, \mathrm{n}=3$ ) of nitrogen fixation (acetylene reduction) in sediment cores vegetated by Zostera marina and amended using the perfusion technique with glucose as a labile carbon source or molybdenum to inhibit the activity of sulfate-reducing bacteria 


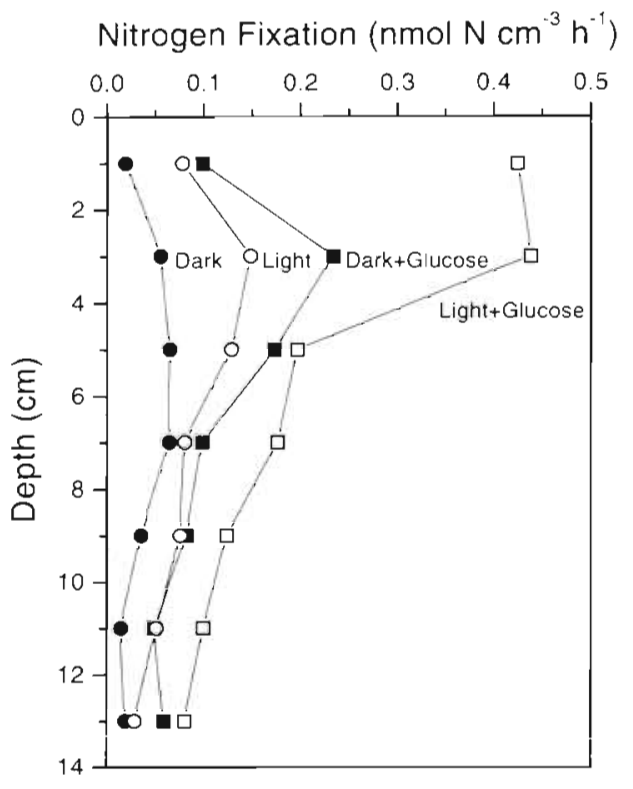

Fig. 8. Depth profiles of light- and dark-incubated intact sediment cores from a Zostera marina bed with or without the addition of glucose to the sediment pore water using the acelylene-reduction perfusion technique

the differences between light and dark incubations throughout the year (Fig. 2). Although temperature also clearly influences bacterial activities (Smith \& Hayasaka 1982), it alone cannot account for the observed differences between light and dark incubations. On a seasonal basis, depth-integrated nitrogen fixation rates were lowest in the winter months, when eelgrass biomass was at a minimum, and then began to increase at the onset of rapid growth in April, reaching

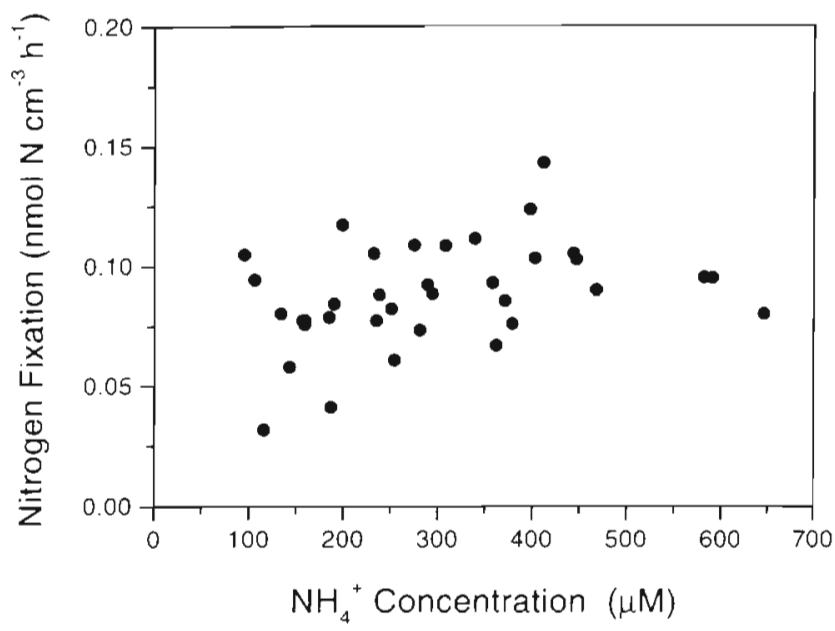

Fig. 9. Relationship between nitrogen fixation (acetylene reduction) and pore water $\mathrm{NH}_{4}^{+}$concentrations on samples taken at $2 \mathrm{~cm}$ depth intervals in triplicate sediment cores containing intact Zostera marina plants

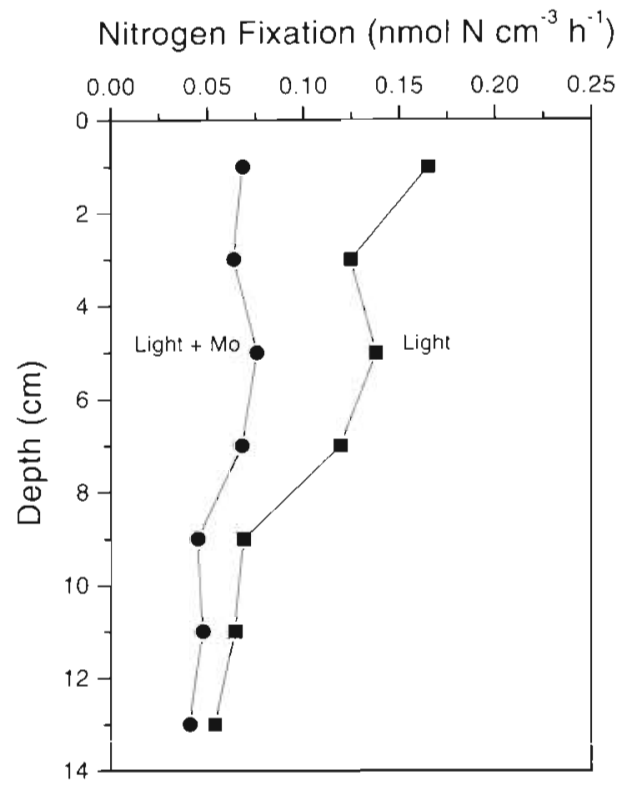

Fig 10. Depth profiles of light-incubated intact sediment cores from a Zostera marina bed using the acetylene-reduction perfusion technique with or without the addition of molybdate to the sediment pore water as an inhibitor of sulfatereducing bacteria

a maximum in August some 4-fold higher than winter rates that coincided with the high summer $Z$. marina biomass and productivity (Pedersen \& Borum 1993, Risgaard-Petersen et al. unpubl.). Rates declined in the fall as colder temperatures and shorter daylength reduced eelgrass growth, but remained relatively high compared to the spring (Fig. 2), perhaps due to the greater eelgrass standing crop or to nitrogen fixation associated with decaying roots and rhizomes (Kenworthy et al. 1987). This seasonal pattern of nitrogen fixation in the eelgrass rhizosphere shows a more detailed correspondence between plant productivity (seagrasses and salt-marsh grasses) and nitrogen fixation than has been shown previously by studies based on quarterly or semi-annual measurements (Capone \& Taylor 1980, Smith \& Hayasaka 1982, Whiting et al. 1986, O'Donohue et al. 1991a, Welsh et al. 1996a).

Differences in the degree of light stimulation of nitrogen fixation activity throughout the year also clearly show the link between plant metabolism and heterotrophic bacterial activity in the eelgrass rhizosphere. This relationship has also been suggested from laboratory experiments that found direct light stimulation of nitrogen fixation in the root zone of the seagrass Zostera carpricorni (O'Donohue et al. 1991a) and the salt-marsh grass Spartina alterniflora (Whiting et al. 1986). In the eelgrass rhizosphere, there was no stimulation of the low nitrogen fixation rates by light during the cold winter months (December to February), presumably because both plant biomass and growth were 
low (Montcreiff et al. 1992, Pedersen \& Borum 1993) and light availability thus had an insignificant effect on plant metabolism. As the growing season progressed with higher temperatures and greater light availability, heterotrophic nitrogen fixation in the light was enhanced 25 to $40 \%$ relative to the dark rates, with the largest differences occurring when seagrass productivity was highest. Welsh et al. (1996a) also found that the difference between nitrogen fixation activity in the rhizosphere of the temperate seagrass Zostera noltii during 4 seasonal light and dark incubations was maximal in the summer and minimal in the winter. In the $Z$. marina rhizosphere, the degree of light stimulation decreased in the fall as lower temperatures and irradiance levels reduced seagrass productivity. The relatively high nitrogen fixation rates in the dark could be due to a larger subsurface carbon input in the fall from decaying roots and rhizomes (Kenworthy et al, 1987) and other organic matter not directly linked to plant metabolism.

Spatial trends in the depth profiles of nitrogen fixation throughout the year provide further evidence that is consistent with the positive influence of plant metabolism on heterotrophic bacterial activity in the rhizosphere. First, nitrogen fixation rates were 2 to $4 \times$ higher in the seagrass-vegetated sediments than in nearby unvegetated sediments, and showed a distinct subsurfare peak in artivity that rorresponded to the depth of maximum seagrass belowground biomass (Fig. 3). Other studies also have shown high nitrogen fixation activity in sediments vegetated by tropical and temperate seagrasses compared to bare sediments, but have not related the subsurface peak to seagrass belowground biomass (Capone \& Taylor 1980, O'Donohue et al. 1991a, Moriarty \& O'Donohue 1993, Welsh et al. 1996b). Second, variations in spatial patterns of depth-specific nitrogen fixation rates during the year were consistent with variations in plant biomass and productivity (Pedersen \& Borum 1993; Fig 4). In the winter months, nitrogen fixation was low and relatively homogenous throughout the sediment core in both the light and dark, a pattern that would be expected if plant metabolism had little effect on bacterial activities when productivity was low. The subsurface peaks in nitrogen fixation activity that later developed during the spring and summer corresponded directly to the variations in Zostera marina belowground biomass measured in April and August (Figs. 4, $5 \& 6)$. Previous studies have shown some depth variation in nitrogen fixation rates in the rhizosphere of several tropical and temperate seagrass species, with highest rates typically in the upper $4 \mathrm{~cm}$ of the sediment (Capone 1982, O'Donohue et al. 1991a, Moriarty \& O'Donohue 1993, Welsh et al. 1996a), but have not related these patterns directly to seagrass root+rhi- zome biomass. Welsh et al. (1996a) found an increase in nitrogen fixation activity in the upper few $\mathrm{cm}$ in the $Z$. noltii rhizosphere between the spring and summer in the Bassin d'Arcachon in southwest France, and suggested that this was due to increased activity of sulfate-reducing bacteria, which were the dominant component of the nitrogen-fixing microflora. Other studies have not shown variation in bacterial activity with depth in seagrass-vegetated sediments (Moriarty \& O'Donohue 1993, Blackburn et al. 1994), possibly because the results were from slurry incubations, or because seagrass metabolism had little effect on sediment bacteria due to low shoot and root densities.

Plant metabolism may directly influence heterotrophic nitrogen fixation activity in the rhizosphere by releasing photosynthetically derived organic carbon from the roots (Moriarty \& Pollard 1982, Moriarty et al. 1986) or by altering $\mathrm{NH}_{4}{ }^{+}$and $\mathrm{O}_{2}$ levels in the rhizosphere (Caffrey \& Kemp 1990, 1992). Both the laboratory experiments with intact root-microbe associations and the high spatial and temporal resolution of the field results indicate that the most plausible explanation for the strong coupling of nitrogen fixation in the eelgrass rhizosphere to plant productivity is stimulation of heterotrophic bacteria by the release of organic exudates from seagrass roots. Heterotrophic bacteria in the seagrass rhizosphere depend to a large extent on the supply of a readily nxidizable organic carbon pool, of which root exudates are a large component (Moriarty \& Pollard 1982, Moriarty et al. 1986). The laboratory experiments with glucose-amended sediment cores clearly showed that the nitrogen-fixing bacteria in the rhizosphere were carbon limited. There was a doubling of nitrogen fixation activity in both the light and dark incubations (Fig. 7), and this stimulation was most pronounced ( 3 to $5 x$ ) in the 1 to $3 \mathrm{~cm}$ depth strata where root biomass was highest (Fig. 8). Slurry incubations of other seagrass-vegetated sediments have sometimes (Capone 1982), but not always (Welsh et al. 1996b), shown carbon stimulation of heterotrophic nitrogen fixation. Unlike the perfusion method which uses whole cores with intact plants, the slurry technique may provide equivocal results in carbon addition experiments because seagrass roots may be damaged during preparation of the sediment slurries, and this may result in the release of internal pools of labile carbon which may artificially increase carbon availability during the incubations (Welsh et al. 1996b). The temporal (seasonal and light vs dark) and spatial (depth profiles) trends in nitrogen fixation activity in the Zostera marina rhizosphere discussed earlier also point to the stimulation of heterotrophic bacteria by a subsurface carbon input linked to plant productivity. Low nitrogen fixation rates and a lack of light stimulation during the winter probably were due to low 
organic carbon inputs from root exudates when plant productivity was low. In the spring and summer, the large differences between light and dark rates and the direct correlation between shifts in root biomass and patterns of nitrogen fixation activity indicate a carbon source related to plant productivity, since root exudation would be expected to be greater during the active growth season and should be most pronounced in the depth interval where belowground biomass is highest.

The link between dissolved organic matter release from plant roots and bacterial activities also has been made to explain temporal dynamics of sulfate reduction in sediments vegetated by the temperate seagrass Zostera noltii (Welsh et al. 1996b), the tropical seagrass Halodule sp. (Blackburn et al. 1994), salt-marsh grasses (Nedwell \& Aziz 1980, Hines et al. 1989), and mangroves (Nedwell et al. 1994). Pollard \& Moriarty (1991) suggested that the spatial pattern of sulfate reduction in sediments colonized by several tropical seagrass species correlated with the belowground distribution of seagrass roots and rhizomes. Additions of molybdate to perfused cores in the $Z$. marina-vegetated sediments showed that sulfate reducers were responsible for $25 \%$ of the nitrogen fixation activity (Figs. $7 \& 10$ ). Other studies have found that sulfatereducing bacteria were responsible for a higher proportion of the nitrogen fixation acitivity in sediment slurries $180 \%$ for $Z$. noltii, Welsh et al, 1996a; 95\% for Z. marina, Capone 1982).

Ammonium control of nitrogen fixation has been demonstrated for a variety of photosynthetic and heterotrophic bacteria, where $\mathrm{NH}_{4}{ }^{+}$additions repress the synthesis of the nitrogenase enzyme responsible for nitrogen fixation (Yoch \& Whiting 1986, Capone 1988). Heterotrophic nitrogen fixation, however, tends to be high in organic-rich marine sediments with relatively high $\mathrm{NH}_{4}{ }^{+}$concentrations (Capone 1988), even though studies on salt marsh sediments have shown that $\mathrm{NH}_{4}{ }^{+}$ can inhibit nitrogen fixation at concentrations as low as 100 to $200 \mu \mathrm{M}$ (Carpenter et al. 1978, Teal et al. 1979. Yoch \& Whiting 1986). We found no direct evidence that $\mathrm{NH}_{4}{ }^{+}$concentrations regulated nitrogen fixation at our study site, and we believe it is unlikely that changes in $\mathrm{NH}_{4}{ }^{+}$availability could account for the temporal and spatial variation in nitrogen fixation during the year. Ammonium concentrations were high (100 to $650 \mu \mathrm{M})$ in the eelgrass rhizosphere, and showed no inverse correlation with acetylene reduction, nor was there an effect of $\mathrm{NH}_{4}{ }^{+}$additions (200 to $800 \mu \mathrm{M}$ ) on acetylene reduction rates (Fig. 9, Table 1). Repression of nitrogenase activity by $\mathrm{NH}_{4}{ }^{+}$is often variable in sediments, both with and without vegetation, and may partly reflect differences in bacterial populations that vary in their susceptibility to $\mathrm{NH}_{4}{ }^{+}$inhibition (Capone 1988, O'Neil \& Capone 1989). It is possible, however, that we did not observe $\mathrm{NH}_{4}{ }^{+}$repression of nitrogen fixation in either the intact cores or sediment slurries because in situ nitrogen fixation activities were already below maximum rates because of the presence of $\mathrm{NH}_{4}{ }^{+}$(Capone 1988), and thus $\mathrm{NH}_{4}{ }^{+}$additions would be unlikely to further decrease nitrogen fixation. rates. This has been shown in studies on the seagrass Zostera marina and the salt-marsh grass Spartina alterniflora, where additions of MSX (L-methionine-D, L-sulfoximine), which is known to negate the repression of nitrogenase synthesis in the presence of $\mathrm{NH}_{4}{ }^{+}$, caused a marked increase in nitrogenase activity and indicated that in situ rates were submaximal (Yoch \& Whiting 1986, Capone 1988). It is also possible that even at the high $\mathrm{NH}_{4}{ }^{+}$concentrations measured in the seagrass rhizosphere, bacterial nitrogen fixation may be favored in localized microzones close to the seagrass roots. Seagrasses decrease $\mathrm{NH}_{\frac{1}{4}}^{+}$concentrations in the vicinity of the roots through direct uptake (Caffrey \& Kemp 1990, 1992), and may therefore compete with bacteria for $\mathrm{NH}_{4}{ }^{+}$(Welsh et al. 1996b). Non-nitrogenfixing bacteria also place a demand on available nitrogen in the rhizosphere. Localized nitrogen limitation could therefore occur in microzones around the roots, but could be missed in the bulk measurements of $\mathrm{NH}_{4}{ }^{+}$ concentrations and acetylene reduction activity.

We also have no evidence that variations in $\mathrm{O}_{2}$ conditions in the rhizosphere could account for the patterns of nitrogen fixation activity in these Zostera marina sediments. Nitrogen fixation in the seagrass rhizosphere (roots+rhizomes and sediments) is typically higher in anoxic or microaerophilic conditions than in oxic conditions (Capone \& Budin 1982, Capone 1988, O'Donohue et al. 1991a) because the nitrogenase enzyme is highly $\mathrm{O}_{2}$ sensitive (Capone 1988). Oxygen released from the roots would tend to have a negative effect, if any, on acetylene reduction rates in the areas of highest root biomass (Capone \& Budin 1982, O'Donohue et al. 1991a). We did not see this negative effect in our study, which suggests that either $\mathrm{O}_{2}$ excretion by the roots was low, or $\mathrm{O}_{2}$ consumption near the roots was high presumably in part due to high sulfate reduction activity (Blaabjerg et al. 1998). The exudation of labile organic compounds from the seagrass roots may also counteract the effects of oxygen release by promoting areas of localized $\mathrm{O}_{2}$ consumption around the roots that may be particularly conducive to heterotrophic nitrogen fixation. Nitrogen fixation activity of bacteria directly associated with the seagrass roots and rhizomes can sometimes be stimulated by fully oxic conditions (Smith \& Hayasaka 1982, O'Donohue et al. 1991a), which could represent a link between seagrass metabolism and heterotrophic nitrogen fixation activity. However, the absence of measurable activity in excised roots and rhizomes in our study 
Table 2. Comparison of nitrogen fixation estimates by acetylene reduction in the rhizosphere of temperate and tropical seagrass beds

\begin{tabular}{|c|c|c|c|c|}
\hline Site & Species & $\begin{array}{l}\text { Season/ } \\
\text { Month }\end{array}$ & $\begin{array}{l}\text { Nitrogen fixation } \\
\left(m g \mathrm{~m} \mathrm{~m}^{-2} \mathrm{~d}^{-1}\right)\end{array}$ & Source \\
\hline \multicolumn{5}{|l|}{ Temperate } \\
\hline Limfjord, Denmark & Zostera marina & Winter & $1.2-2.7^{a}$ & This study \\
\hline Limfjord, Denmark & Zostera marina & Spring & $1.5-2.6^{\mathrm{c}}$ & This study \\
\hline Limfjord, Denmark & Zostera marina & Summer & $4.2-6.0^{d}$ & This study \\
\hline Limfjord, Denmark & Zostera marina & Fall & $3.1-5.5^{i i}$ & This study \\
\hline Great South Bay, New York, USA & Zostera marina & Summer & $3.9-6.5^{\mathrm{b}}$ & Capone (1982) \\
\hline Vaucluse Shores, Virginia, USA & Zostera marina & Summer & $5.2^{b}$ & Capone (1982) \\
\hline Bassin d'Arachon & Zostera noltii & Spring & $0.2-0.4^{c}$ & Welsh et al. (1996a) \\
\hline Bassin d'Arachon & Zostera noltii & Summer & $2.0-7.3^{\circ}$ & Welsh et al. (1996a) \\
\hline Bassin d'Arachon & Zostera noltii & Fall & $1.8-4.4^{c}$ & Welsh et al. (1996a) \\
\hline Bassin d'Arachon & Zostera noltii & Winter & $0.1-0.2^{c}$ & Welsh et al. (1996a) \\
\hline \multicolumn{5}{|l|}{ Tropical and subtropical } \\
\hline Gulf of Carpentaria, Australia & $\begin{array}{l}\text { Syringodium isoetifolium } \\
\text { Cymodocea serrulata }\end{array}$ & Feb & $16-47^{d}$ & Moriarty \& O'Donohue (1993) \\
\hline Gulf of Carpentaria, Australia & $\begin{array}{l}\text { Thalassia hemprichii } \\
\text { Cymodocea serrulata }\end{array}$ & Feb & $13-19^{\mathrm{e}}$ & Moriarty \& O'Donohue (1993) \\
\hline Gult of Carpentaria, Australia & Enhalus acoroides & Nov & $25^{i}$ & Moriarty \& O'Donohue (1993) \\
\hline Moreton Bay, Australia & Zostera capricorni & Summer & $25-40^{9}$ & O'Donohue et al. (1991a) \\
\hline Moreton Bay, Australia & Zostera capricorni & Winter & $10^{9}$ & O'Donohue et al. (1991a) \\
\hline Barbados & Thalassia testudinum & Sep & $27-140^{h}$ & Patriquin \& Knowles (1972) \\
\hline Bimini Harbor, Bahamas & Thalassia testudinum & Jul & $5.1-5.3^{i}$ & Capone et al. (1979) \\
\hline Florida, USA & Thalassia testudinum & Mar, Jan & $0.03^{\prime}$ & McRoy et al. (1973) \\
\hline Biscayne Bay, Florida, USA & Thalassia testudinum & Aug, Oct & $7.5-24.3^{k}$ & Capone \& Taylor (1980) \\
\hline Bimini Harbor, Bahamas & Thalassia testudinum & Aug & $5.3-12.1^{k}$ & Capone \& Taylor (1980) \\
\hline Jamaica & Halodule beaudetti & Dec & $14^{1}$ & Blackburn et al. (1994) \\
\hline \multicolumn{5}{|c|}{$\begin{array}{l}\text { "Acetylene added to pore water of intact cores containing plants by perfusion and incubated in light or dark. Daily rates inte- } \\
\text { grated to depth of } 14 \mathrm{~cm} \text { calculated using average number of daylight and dark hours per month and dinitrogen conversion } \\
\text { ratio of } 3: 1\end{array}$} \\
\hline \multicolumn{5}{|c|}{$\begin{array}{l}\text { 'Slurry incubations of } 12 \mathrm{~cm} \text { deep sediment cores containing both sediments and roots. Daily rates calculated using dinitro- } \\
\text { gen conversion ratio of } 2.6: 1 \text { and assuming a constant rate for } 24 \mathrm{~h}\end{array}$} \\
\hline \multicolumn{5}{|c|}{$\begin{array}{l}\text { "Acetylene added to headspace of intact sediment cores containing plants. Nitrogen fixation calculated using 3:1 dinitrogen } \\
\text { conversion ratio }\end{array}$} \\
\hline \multicolumn{5}{|c|}{ 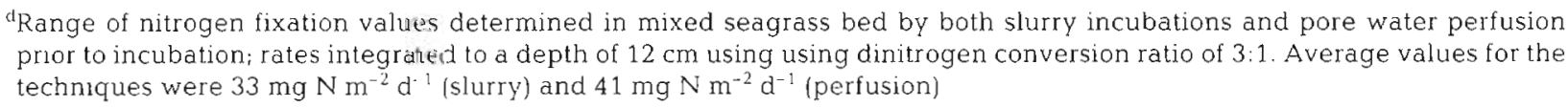 } \\
\hline \multicolumn{5}{|c|}{$\begin{array}{l}\text { eRange of nitrogen fixation values determined in mixed seagrass bed by both slurry incubations and pore water perfusion } \\
\text { prior to incubation; rates integrated to a depth of } 7 \mathrm{~cm} \text { using using dinitrogen conversion of } 3: 1 \text {. Average values for the tech- } \\
\text { niques were } 16 \mathrm{mg} \mathrm{N} \mathrm{m} \mathrm{N}^{-2} \mathrm{~d}^{-1} \text { (slurry) and } 15 \mathrm{mg} \mathrm{N} \mathrm{m}^{-2} \mathrm{~d}^{-1} \text { (perfusion) }\end{array}$} \\
\hline \multicolumn{5}{|c|}{$\begin{array}{l}\text { 'Fixation determined by slurry incubation of sediments without roots, integrated to a depth of } 12 \mathrm{~cm} \text { using } 3: 1 \text { dinitrogen con- } \\
\text { version ratio }\end{array}$} \\
\hline \multicolumn{5}{|c|}{$\begin{array}{l}\text { PPore water of intact sediment cores containing plants perfused with acetylene-amended water prior to incubation. Calcula- } \\
\text { tion of fixation based on }{ }^{15} \mathrm{~N} \text { calibration yielding dinitrogen conversion ratio of } 3: 0.95\end{array}$} \\
\hline \multicolumn{5}{|c|}{$\begin{array}{l}\text { "Slurry incubations of sediments including roots and rhizomes. Annual fixation rates based on dinitrogen conversion ratio af } \\
3: 1 \text { were converted to daily rates assuming } 365 \mathrm{~d} \mathrm{yr}^{-1} \text { in tropics }\end{array}$} \\
\hline \multicolumn{5}{|c|}{$\begin{array}{l}\text { 'Slurry incubation of } 20 \mathrm{~cm} \text { sediment cores divided into } 0-10 \mathrm{~cm} \text { and } 10-20 \mathrm{~cm} \text { sections; fixation calculated using dinitrogen } \\
\text { conversion ratio of } 3: 1\end{array}$} \\
\hline \multicolumn{5}{|c|}{$\begin{array}{l}\text { Maximum rate measured on sediments containing roots and rhizomes in flasks to which acetylene-amended seawater was } \\
\text { added }\end{array}$} \\
\hline \multicolumn{5}{|c|}{$\begin{array}{l}{ }^{k} \text { Slurry incubations including roots, thizomes and sediments integrated to a depth of } 20 \mathrm{~cm} \text { and converted to nitrogen fixation } \\
\text { based on 3:1 dinitrogen conversion ratio. Hourly rates were converted to daily rates by multiplying by } 24\end{array}$} \\
\hline \multicolumn{5}{|c|}{$\begin{array}{l}\text { 'Acetylene-saturated seawater injected at } 0.5 \mathrm{~cm} \text { intervals into } 7 \mathrm{~cm} \text { sediment core; overlying water adjusted to } 10 \% \text { satura- } \\
\text { tion. Samples taken from sediment slurries following incubation }\end{array}$} \\
\hline
\end{tabular}


indicates that this was probably not responsible for the patterns we observed.

Overall, daily nitrogen fixation rates integrated to a depth of $14 \mathrm{~cm}$ measured in this study (1 to $6 \mathrm{mg} \mathrm{N} \mathrm{m}^{-2}$ $\mathrm{d}^{-1}$ ) were lower than rates typically measured in tropical and subtropical seagrass beds (5 to $140 \mathrm{mg} \mathrm{N} \mathrm{m}^{-2}$ $\mathrm{d}^{-1}$; Table 2), but were comparable to rates measured in other eelgrass beds ( 3 to $7 \mathrm{mg} \mathrm{N} \mathrm{m}^{-2} \mathrm{~d}^{-1}$; Table 2) and temperate seagrass sediments $\left(<1\right.$ to $7 \mathrm{mg} \mathrm{N} \mathrm{m}^{-2}$ $\mathrm{d}^{-1}$; Table 2). The annual rate of heterotrophic nitrogen fixation in the Zostera marina rhizosphere based on monthly light/dark rates and corrected for the average number of light and dark hours each month was $1.3 \mathrm{~g}$ $\mathrm{N} \mathrm{m}^{-2} \mathrm{yr}^{-1}$. This value is very similar to that calculated for $Z$. marina in New York $\left(0.84 \mathrm{~g} \mathrm{~N} \mathrm{~m}^{-2} \mathrm{yr}^{-1}\right)$ and Virginia, USA (1.0 $\mathrm{g} \mathrm{N} \mathrm{m}^{-2} \mathrm{yr}^{-1}$ ) (Capone 1982, calculated by Howarth et al. 1988), and for $Z$. noltii in southwest France $\left(0.4\right.$ to $1.1 \mathrm{~g} \mathrm{~N} \mathrm{~m}^{-2} \mathrm{yr}^{-1}$ : Welsh ef at. 1996a). Kenworthy et al. (1987) also reported a somewhat lower rate of $0.57 \mathrm{~g} \mathrm{~N} \mathrm{~m}^{-2} \mathrm{yr}^{-1}$ only for nitrogen fixation associated with $Z$. marina detritus in a North Carolina (USA) seagrass meadow. This fixed $N$, once mineralized, may be taken up by the plant roots, diffuse to the water column, or be lost via denitrification (Caffrey \& Kemp 1990, Hemminga et al. 1991, Pedersen \& Borum 1993). If we use the annual $\mathrm{N}$ incorporation value of $34.5 \mathrm{~g} \mathrm{~N} \mathrm{~m}^{-2} \mathrm{yr}^{-1}$ determined by Pedersen \& Borum (1993) for a comparable $Z$. marina population in another location in Denmark, we can estimate the potential significance of the measured nitrogen fixation rates to $Z$. marina. Of the total annual $\mathrm{N}$ demand $73 \%$ of which we assume was provided by external $N$ sources ( $51 \%$ from sediment, $49 \%$ from water column) and $27 \%$ by internal $\mathrm{N}$ recycling (Pedersen \& Borum 1993), our nitrogen fixation rates could potentially provide approximately $5 \%$ of the annual external $\mathrm{N}$ incorporation and $10 \%$ of that derived from sediment sources. Nitrogen fixation in these sediments accounted for less than $4 \%$ of the measured $N$ inputs from April through August (Risgaard-Petersen et al. unpubl.). Depth-integrated rates of denitrification in the same eelgrass meadow measured during April and August were $30 \%$ (April) and $75 \%$ (August) lower than nitrogen fixation rates, and thus did not balance inputs from nitrogen fixation (Risgaard-Petersen et al. unpubl.).

Our data from intact sediment-plant associations clearly indicate a direct coupling of rhizosphere nitrogen fixation to Zostera marina productivity and support the hypothesis that heterotrophic nitrogen fixation is at least partly dependent on the exudation of photosynthetically derived organic carbon from seagrass roots. The detailed temporal and spatial patterns of nitrogen fixation reported here from perfusion incubations that maintain direct root-microbe associations indicate the importance of macrophytes as a source of labile carbon to heterotrophic bacteria, with $\mathrm{NH}_{4}{ }^{+}$and $\mathrm{O}_{2}$ concentrations in the sediment pore water having minor or secondary roles. What remains unclear is the exact nature of the association between the eelgrass and microbes that defines this close coupling of plant productivity and nitrogen fixation. Previous studies have suggested the possibility of a symbiotic association between marine macrophytes (seagrasses and salt-marsh grasses) and nitrogen-fixing heterotrophic bacteria in direct contact with the roots, involving a bidirectional exchange of materials (Capone \& Budin 1982, Whiting et al. 1986). Capone (1988) provided some evidence of this from incubations of individual $Z$. marina plants in which the roots and rhizomes were exposed to ${ }^{15} \mathrm{~N}_{2}$, showing that a significant amount of fixed $\mathrm{N}$ was incorporated into the root, rhizome and leaf tissue after $48 \mathrm{~h}$. Further studies using isotopic tracers would help clarify whether this exchange is rapid through direct transfer of metabolites in both directions or whether it is more indirect, depending on the longer-term dynamics of mineralization and plant uptake.

Acknowledgements. Kitte Gerlich and Egon Frandsen provided valuable technical and field assistance. We thank Jens Wurgler Hansen for the belowground biomass data and Peter Berg for advising on the diffusion calculations. Financial support was provided by the Danish Environmental Research Program and the Danish National Science Research Councils. This work is a contribution from the European Union ELOISE (European Land-Ocean Interaction Studies) program (ELOISE publication \#051) in the framework of the NICE project carried out under contract \#MAS3-CT96-0048

\section{LITERATURE CITED}

Blaabjerg V, Mouritsen KN, Finster K (1998) Diel cycles of sulphate reduction rates in sediments of a Zostera marina bed (Denmark). Aquat Microb Ecol 15:97-102

Blackburn TH, Nedwell DB, Wiebe WJ (1994) Active mineral cycling in a Jamaican seagrass sediment. Mar Ecol Prog Ser 110:233-239

Boon PI, Moriarty DJW, Saffigna PG (1986a) Rates of ammonium turnover and the role of amino-acid deamination in seagrass (Zostera capricorni) beds of Moreton Bay, Australia. Mar Biol 91:259-268

Boon PI, Moriarty DJW, Saffigna PG (1986b) Nitrate metabolism in sediments from seagrass (Zostera capricorni) beds of Moreton Bay, Australia. Mar Biol 91:269-275

Bower E, Holm-Hansen A (1980) A salicylate-hypochlorite method for determining ammonia in seawater. Can J Fish Aquat Sci 37:794-798

Caffrey JM, Kemp WM (1990) Nitrogen cycling in sediments with estuarine populations of Potamogeton perfoliatus and Zostera marina. Mar Erol Prog Ser 66:147-160

Caffrey JM, Kemp WM (1992) Influence of the submersed plant, Potamogeton perfoliatus, on nitrogen cycling in estuarine sediments. Limnol Oceanogr 37:1483-1495 
Capone DG (1982) Nitrogen fixation (acetylene reduction) by rhizosphere sediments of the eelgrass Zostera marina Mar Ecol Prog Ser 10:67-75

Capone DG (1988) Benthic nitrogen fixation: microbiology, physiology and ecology. In: Blackburn TH, Sorensen J, Roswall $T$ (eds) Nitrogen cycling in marine coastal environments. SCOPE Series. J Wiley \& Sons, New York, p 85-123

Capone DG, Budin JM (1982) Nitrogen fixation associated with the rinsed roots and rhizomes of the eelgrass Zostera marina. Plant Physiol 70:1601-1604

Capone DG, Carpenter EJ (1982) Nitrogen fixation in the marine environment. Science 217:1140-1142

Capone DG, Penhale PA, Oremland RS, Taylor BF (1979) Relationship between productivity and $\mathrm{N}_{2}\left(\mathrm{C}_{2} \mathrm{H}_{2}\right)$ fixation in a Thalassia testudinum community. Limnol Oceanogr $24: 117-125$

Capone DG, Taylor BF (1980) $\mathrm{N}_{2}$ fixation in the rhizosphere of Thalassia testudinum. Can J Microbiol 26:998-1005

Carpenter EJ, Van Raalte CD, Valiela 1 (1978) Nitrogen fixation by algae in a Massachusetts salt marsh. Limnol Oceanogr 23:318-327

Christensen PB, Sorensen J (1986) Temporal variation of denitrification activity in plant-covered, littoral sediment from Lake Hampen, Denmark. Appl Environ Microbiol 51: $1174-1179$

Hemminga MA, Harrison PJ, van Lent $F$ (1991) The balance of nutrient losses and gains in seagrass meadows. Mar Ecol Prog Ser 7 1:85-96

Hines ME, Banta GT, Giblin AE, Hobbie JE (1994) Acetate concentrations and oxidation in salt-marsh sediments Limnol Oceanogr 39:140-148

Hines ME, Knollmeyer SL, Tugel JB (1989) Sulfate reduction and othor sodimentary biogeochemistry in a northern New England salt marsh. Limnol Oceanogr 34:578-590

Howarth RW (1988) Nutrient limitation of net primary production in marine ecosystems. Annu Rev Ecol Syst 19: $89-110$

Howarth RW, Marino R, Lane J. Cole JJ (1988) Nitrogen fixation in freshwater, estuarine, and marine ecosystems. 1. Rates and importance. Lumnol Oceanogr 33:669-687

Jizumu H, Hattori A, McRoy CP (1980) Nitrate and nitrite in interstitial waters of eelgrass beds in relation to the rhizosphere. J Exp Mar Biol Ecol 47:191-201

Kenworthy WJ, Currin C, Smith G. Thayer G (1987) The abundance, biomass and acetylerie reduction activity of bacteria associated with decomposing rhizomes of two seagrasses, Zostera marina and Thalassia testudinum. Aquat Bot 27:97-119

McRoy CP, Goering JJ, Chaney B (1973) Nitrogen fixation associated with seagrasses. Limnol Oceanogr 18:998-1002

Moncreiff CA, Sullivan MJ, Daehnick AE (1992) Primary production dynamics in seagrass beds of Mississippi Sound: the contributions of seagrass, epiphytic algae, sand microflora, and phytoplankton. Mar Ecol Prog Ser 87. $161-171$

Moriarty DJW, Iverson R, Pollard PC (1986) Exudation of organic carbon by the seagrass Halodule wrightii and its effect on bacterial growth in the sediment. J Exp Mar Biol Ecol 96:115-126

Moriarty DJW, O'Donohue MJ (1993) Nitrogen fixation in seagrass communities during summer in the Gulf of Carpentaria, Australia. Aust J Mar Freshwat Res 44:117-125

Moriarty DJW, Pollard PC (1982) Diel variation in bacterial productivity in seagrass (Zostera capricorni) beds measured by rate of thymidine incorporation into DNA. Mar Biol 72:165-173
Nedwell DB, Aziz SA (1980) Heterotrophic nitrogen fixation in an untertidal saltmarsh sediment. Estuar Coast Mar Sci 10:699-702

Nedwell DB, Blackburn TH, Wiebe WJ (1994) Dynamic nature of the turnover of organic carbon, nitrogen and sulphur in the sediments of a Jamaican mangrove forest. Mar Ecol Prog Ser 110:223-231

Nixon SW, Pilson MEQ (1983) Nitrogen in estuarine and coastal marine ecosystems. In: Carpenter EJ, Capone DG (eds) Nitrogen in the marine environment. Academic Press, New York, p 565-647

O'Donohue MJ, Moriarty DJ, MacRae IC (1991a) Nitrogen fixation in sediments and the rhizosphere of the seagrass Zostera capricorni. Microb Ecol 22:53-64

O'Donohue MJ, Moriarty DJ, MacRae IC (1991b) A comparison of methods for determining rates of acetylene reduction (nitrogen fixation) by heterotrophic bacteria in seagrass sediment. J Microbiol Methods 13:171-183

O'Neil JM, Capone DG (1989) Nitrogenase activity in tropical carbonate marine sediments. Mar Ecol Prog Ser 56: $145-156$

Oremland RS, Capone DG (1988) Use of 'specific' inhibitors in biogeochemistry and microbial ecology. Adv Microb Ecol $10: 285-383$

Oremland RS, Taylor BF (1977) Diurnal fluctuations of $\mathrm{O}_{2}, \mathrm{~N}_{2}$ and $\mathrm{CH}_{4}$ in the rhizosphere of Thalassia testudinum. Limnol Oceanogr 22:566-570

Patriquin D, Knowles R (1972) Nitrogen fixation in the rhizosphere of marine angiosperms. Mar Biol 16:49-58

Pedersen MF, Borum J (1993) An annual nitrogen budget for a seagrass Zostera marina population. Mar Ecol Prog Ser 101:169-177

Pollard PC, Moriarty DJW (1991) Organic carbon decomposition, primary and bacterial productivity, and sulphate reduction, in tropical seagrass beds of the Gulf of Carpentaria, Australia. Mar Ecol Prog Ser 69:149-159

Rysgaard S, Berg P (1996) Mineralization in a northeastern Greenland sediment: mathematical modelling, measured sediment pore water profiles and actual activities. Aquat Microb Ecol 11:297-305

Seitzinger SP, Garber JH (1987) Nitrogen fixation and ${ }^{15} \mathrm{~N}_{2}$ calibration of the acetylene reduction assay in coastal marine sediments. Mar Ecol Prog Ser 37:65-73

Shieh WY, Simidu U, Maruyama Y (1989) Enumeration and characterization of nitrogen-fixing bacteria in an eelgrass (Zostera marina) bed. Microb Ecol 18:249-259

Smith GW, Hayasaka SS (1982) Nitrogenase activity associated with Zostera marina from a North Carolina estuary Can J Microbiol 28:448-451

Taylor BF, Oremland RS (1979) Depletion of adenosine triphospate in Desulfovibrio by oxyanions of group Vl elements. Curr Microbiol 3:101-103

Teal TM, Valiela I, Berlo D (1979) Nitrogen fixation by thizosphere and free-living bacteria in salt marsh sediments. Limnol Oceanogr 24:126-132

Welsh DT, Bourques S, de Wit R. Herbert RA (1996a) Seasonal variations in nitrogen-fixation (acetylene reduction) and sulphate-reduction rates in the rhizosphere of Zostera noltii: nitrogen fixation by sulphate-reducing bacteria. Mar Biol 125:619-628

Welsh DT, Wellsbury P, Bourgues S, de Wit R, Herbert RA (1996b) Relationship between porewater organic carbon content, sulphate reduction and nitrogen fixation (acetylene reduction) in the rhizosphere of Zostera noltii. Hydrobiologia 329:175-183

Wetzel RG, Penhale PA (1979) Transport of carbon and excre. tion of organic carbon by leaves and root/rhizomes in sea- 
grasses and their epiphytes. Aquat Bot 6:149-158

Whiting GJ, Gandy EL, Yoch DC (1986) Tight coupling of root-associated nitrogen fixation and plant photosynthesis in the salt marsh grass Spartina alterniflora and carbon dioxide enhancement of nitrogenase activity. Appl Envi-

Editorial responsibility: Kenneth Heck Jr (Contributing Editor), Dauphin Island, Alabama, USA ron Microbiol 52:108-113

Yoch DC, Whiting GJ (1.986) Evidence for $\mathrm{NH}_{4}{ }^{+}$switch-off regulation of nitrogenase activity by bacteria in salt marsh sediments and roots of the grass Spartina alterniflora. Appl Environ Microbiol 51:143-149

Submitted: August 27, 1997; Accepted: May 4. 1998 Proofs received from author(s): June 23, 1998 